\title{
BIM and Cultivation of Civil Engineering Application Talents in Colleges and Universities
}

\author{
Lisheng Liu \\ College of Urban Construction, Wuchang University of Technology, 430223, China
}

Keywords: BIM, Cultivation of civil engineering talents, Course development, laboratory construction.

\begin{abstract}
There is a broad space for application of building Information Modeling (BIM) in constructional engineering field, and BIM is of high value in cultivation of civil engineering application talents in colleges and universities. This paper aims to, through analyzing the positive effect of BIM on cultivation of civil engineering talents in colleges and universities, discuss how to meet the needs of the construction industry, reform the existing teaching mode and methods, and develop BIM courses, so as to largely improve the cultivation quality of civil engineering application talents in colleges and universities.
\end{abstract}

\section{Introduction}

BIM refers to building digital building model based on related information data of construction project. On one hand, the comprehensive real information of building can be simulated on the basis of digital information integrated in the same model platform. On the other hand, interested parties of project can take full advantage of and share information in the model, to guarantee unimpeded access to information, ensure seamless connection of design, construction and operation management of construction project, and realize method and approach informationalization throughout the project period.

BIM is a huge revolution in the construction industry. With the fast development of information technology and the construction industry, that BIM technology is widely used in the construction technology has become a general trend. Hence, integrating BIM technology into the cultivation of civil engineering application talents in colleges and universities complies with the development and market requirement of the construction industry, and is urgent for the cultivation of new-type engineering and technical talents mastering innovative tools and having innovative consciousness.

\section{Application Status of BIM in Constructional Engineering Field}

BIM was firstly proposed as a terminology in the engineering construction industry in 2002, and was first applied in the construction field in western developed countries. The American government has implemented the national 3D-4D-BIM program since 2013, and has stipulated that BIM technology must be employed for planning and design of all major projects since 2016. The British government explicitly demanded enterprises to realize comprehensive synergetic development of 3D-BIM by 2013. The South Korean government planned to realize that BIM technology is employed for all public works by 2016. The Singapore government has set up BIM fund, and planned that over 80\% construction enterprises employ BIM technology by 2016. In Japan, the building information technology software industry has set up a national solution software alliance, planning to take BIM application as a design standard of all housing construction projects. Since the introduction of BIM technology in 2003, the BIM concept has been coming into play in the construction industry in China. With the acceleration of China's urbanization, China's construction industry has been developing at a 
fast speed, and the fast permeation and wide application of BIM technology in the construction industry become a necessary trend. In 2011, the Ministry of Housing and Urban-Rural Development of the People's Republic of China (MOHURD) took BIM technology to be one of the focal points of the "Twelfth-Five Period" informationalization development program of the industry with the Information Development of Construction Industry during 2011-2015. The Guiding Opinion on Application and Promotion of BIM Technology in Shanghai promulgated on October 29, 2014 provides that BIM technology application should be realized in design and construction phases of government-invested projects, large-scale public buildings and major projects in which the investment amount exceeds RMB100 million or of which the individual building covers an area of more than 20,000 $\mathrm{m} 2$, and of projects for which an application for being identified as green building or for national excellent survey and design award or construction award in Shanghai since 2017. In 2015, policies and standards on application and promotion of BIM technology were made in Beijing, Guangdong, Shandong, etc.

In recent years, BIM technology has been applied in several large-scale projects, including China's tallest building Shanghai Center, Beijing's tallest building Beijing of China Honor, Central China's tallest building Wuhan Center, and so on. Presently, BIM technology is mainly applied in three phases in the engineering construction in China, namely design phase, construction phase and operation phase. In the design phase, three-dimension integration collaborative design is realized to present truthful and accurate three-dimensional model, virtual construction and collision test can be performed to reduce the incidence of "error, collision and omission", and the spatial state of complex water, heating, power, and fire pipeline systems can be displayed in BIM software clearly to largely improve the feasibility and effectiveness of design, and provide strong support to efficient construction. In the construction phase, the construction process of each part and the cost information of components and members can be got access to via three-dimensional image to realize visual control and management throughout the construction process and effectively control cost and reduce risk. In the operation phase, operation of the whole working environment and maintenance of all facilities can be realized on the basis of computable collaborative information of construction project, to timely and effectively perform operation, maintenance and management. The project of China Expo Complex proved that: 90\% drawing errors, 60\% reworking, and 10\% construction period can be reduced by BIM technology, so that project benefits are largely increased.

Presently, the application of BIM technology in China mainly rests in design phase, and BIM technology has a wide prospect in construction and operation phases. With the heavy promotion of the central government and local governments, the application of BIM technology is bound to give rise to a new reform in the construction industry and the engineering cost management field.

\section{Positive Effect of BIM on Cultivation of Civil Engineering Talents in Colleges and Universities}

The main existing classroom teaching mode of civil engineering specialty refers to teachers' delivering lectures plus students' independently studying. Most courses of civil engineering specialty are boring and dull, so that many students are not enthusiastic learners. To a certain extent, these factors affect the teaching effect, and are harmful to students themselves. BIM technology is characterized by visuality and simulation. The introduction of BIM technology into classroom teaching can stimulate students' learning interest, and make students feel satisfied for practicing what they learnt. On one hand, students can carry out virtual wandering of building, see the doors, windows and walls of building, and layout of system line, have a rough understanding of the shape of building after completion via BIM software, learn about the conditions on construction site based on three-dimensional model, simulate the data application process of construction worker, construction budget and materialman, and get a clear perceptual knowledge of building. On the other hand, students can make use of BIM software to perform collision test to get real-time node collision results, to visually identify irrational node of project without personal participation in engineering construction, and make rational analysis based on their knowledge. This can check what they have learned. 
The specialty of civil engineering is requires much practice. Therefore, the practice and practical training are particularly important in talent cultivation. Engineering construction products, however, are of large size, need high investment, take a long time, and subject to field security restriction. Thus, it is difficult for civil engineering majors to follow up a project in progress for a long time. Even though students have enough time to do so, few construction units will accept them. The 3D-4D-5D BIM model can act as project carrier for practice and practical training teaching of civil engineering majors, with which the difficulty of implementing practice and practical training in combination with field practice from time to time. Generally, BIM model is three-dimensional, and two-dimensional plane, elevation and section can be generated on this basis. Under the aid of visualization functions, teachers lead students to switch between 3D and 2D freely, and practice reading engineering drawing and identifying building construction. A 4D BIM model contains construction schedule. Virtual construction of building can be realized with computer first, so as to guide students to practice construction technique and construction organization management without worry about construction period and field security. A 5D BIM model contains construction cost information, which can automatically generate a detailed statement of labor, material, equipment and capital in construction phase, and help students to practice engineering measurement and valuation, and cost management.

Besides, students who complete part of major courses can take part in professional BIM competition with BIM-related course design to consolidate their knowledge base, and independently complete a construction project from design, construction, cost estimate to later-stage maintenance with BIM technology for their graduation project to check the systematicness and completeness of what they learnt. Thus, what students learnt can comply with the actual situation of construction market, and students can adapt to society demands better.

\section{BIM Course Development in Civil Engineering Teaching}

With the wide promotion of BIM technology application, it is imperative to optimize and reconstruct the course system of civil engineering specialty in colleges and universities. BIM course system should be constructed on the basis of change of the demands of the industry and enterprises for civil engineering technicist, BIM building model courses should be offered in combination with actual construction, and BIM course module should be integrated into architectural drawing reading, building materials, construction equipment, building construction, engineering measurement and evaluation and other related courses to construct BIM courses in line with industry needs.

(1) Architectural drawing reading + BIM model. With the application of BIM technology in architectural drawing reading course, students can make themselves master of plane method altas by the aid of visual 3D model, and then identify some possible discrepancy between structure and building, self collision of pipe, etc. Thus, students, on one hand, can deepen their understanding of design drawing, and on the other hand, can simulate drawings reviewing and identify and solve design defects with the aid of BIM technology.

(2) Building materials + BIM model. Students can perform building material performance test, cost control, BIM-based material management, purchasing management, warehouse management, settlement payments, comparison of quota material, material tracking, and demand plan with the actual situation, and material cost analysis, etc. via building material laboratory and BIM technology.

(3) Construction equipment + BIM model. Pipeline layout can be completed rapidly with the aid of BIM technology. There are problems difficult to be foreseen in heating, ventilation, water supply and drainage, fire protection, and strong and weak electricity works due to construction site situation, professional coordination and technological differences. Visual BIM software can help collision test and accurately reserving and embedding, to enhance students' comprehensive practice ability.

(4) Building construction technology + BIM model. BIM 4D model is applied in building construction technology course for virtual construction to simulate construction progress, including arrangement of construction site, construction site coordination, and completed model delivery, to visually simulate coordination and communication among interested parties, construction organization and construction progress. The dynamic simulation of construction technology and 
comparison of construction and process schemes in respect of operability with BIM construction management software can help students to deepen their understanding of construction regions, to guarantee construction progress and optimize construction scheme.

(5) Engineering measurement and evaluation + BIM model. For BIM technology-based cost control, a 5D building information model is required, namely integrating bill of quantities, fixed pricing and other cost information into 4D model. With a 5D BIM, students can carry out virtual construction, and automatically generate the quantity of labor, materials and machinery required in each construction phase, to establish a resource requirements planning. Besides, monthly engineering report can be developed by automatic calculation of 5D model based on construction progress. The actual expenses on materials consumption, machinery settlement and labor subcontracting can be calculated, and comparative analysis of investment estimation, design estimation and working drawing estimation can be made based on actual cost, budget cost, and contractual income, so as to take effective measures and perform dynamic analysis and control of cost.

\section{Realization of BIM Laboratory and BIM Teacher Training by Cooperation between School and Enterprise}

Schools cooperating with enterprises to build BIM laboratory can guarantee BIM talent cultivation. Civil engineering colleges can, based on their original cooperative relationship with enterprises, take the chance of BIM technology application to actively cooperate with construction company, BIM software development company and scientific research institute to build BIM laboratory, to push BIM technology to truly"take root" in civil engineering specialty. Concerning the problem of poor operating ability of students, colleges can introduce VR technology to build virtual laboratory. BIM technology-based virtual laboratory can be combined with physical laboratory to reduce the operating cost of the latter. Poor connection among courses of civil engineering specialty is a prominent defect. To overcome this defect, BIM laboratory can come into play, with which students can systematically integrating the specialized knowledge they learnt, so that they can get a comprehensive clear understanding about their specialized knowledge, and improve their practical ability and innovation ability. For building a BIM laboratory, proper BIM should be selected. The BIM software widely used in China include Glodon, rib, Bentley, ArchiCAD, thsware, and Gstar BIM, each of which has its own distinctions. Colleges should select proper BIM software based on their specialty features.

With the wide promotion of BIM technology in construction industry, the demand for BIM technology talents increasingly rises. To solve BIM teacher shortage, the government, colleges and enterprises should take measures together. Specifically, the government or industry association takes the lead to establish a BIM application technology alliance, regularly holds BIM application technology training and seminar, and invites specialists to deliver lectures in combination with engineering projects, to consolidate the reserve of BIM technology talents, and optimize the allocation of BIM talent resources. Besides, BIM technology pilot application can be carried out. BIM teaching and scientific research teams of civil engineering specialty can be built, and visual teaching mode can be built, to quicken the cultivation of BIM technology talents.

\section{Conclusion}

BIM, a new technology in the construction field, will be a general trend in the construction field. The fundamental objective of teaching reform of higher educational institutions is to improve the quality of talent cultivation. The civil engineering specialty which outputs application-orientation construction technology talents must keep pace with the market orientation, actively offering BIM-related courses, improving students' professional skills and ability, transporting qualified new-type professionals to the construction industry, and making contributions to the sound development of Chinese construction industry information. 


\section{References}

[1] Zeng Wenhai, Fu Weiming. A Study on Application of BIM Technology in Teaching in Colleges and Universities, Journal of Heilongjiang Vocational Institute of Ecological Engineering, 2014.11.

[2] Tu Jinsong, Li Ruixia. Building of Comprehensive Training Platform of Civil Engineering Specialty Based on BIM Technology Application, Journal of Hefei University, 2015.7.

[3] Liu Hongyong, He Weitao. Exploration on the Means of BIM Practical Teaching of Ordinary Institutions of Higher Learning, Journal of Information Technology in Civil Engineering and Architecture, 2013.5.

[4] Xu Guiming. BIM View: Measures for Overcoming the Difficulties of Curriculum Reform of Civil Engineering Specialty of Higher Vocational Colleges, Higher Vocational Studies of Changzhou Institute of Engineering Technology, 2014.1. 